dự phòng heparin và theo dõi lâm sàng, sau 1 tuần suy giảm các triệu chứng.

Ca tai biến nặng hơn đó là Onyx trào nhiều vào xoang tĩnh mạch, rồi lan tĩnh mạch vỏ não, nguyên nhân do dị dạng với nhiều điểm rò lan tỏa dọc theo xoang ngang - sigma bên trái, chiều dài bóng không đủ bao phủ phía trên và dưới các điểm rò, tuy chúng tôi đã cố gắng di chuyển bóng dự đoán theo hướng lan của Onyx để chẹn bảo vệ xoang. Dị dạng được can thiệp bít tắc hoàn toàn, tuy nhiên sau can thiệp khoảng 1 giờ, bệnh nhân xuất hiện mất tri giác và hôn mê, chụp CLVT cho thấy khối máu tụ lớn nhu mô thùy thái dương trái, bệnh nhân được mở sọ cấp cứu sau đó, chăm sóc điều trị tích cực, điểm mRs 5 sau can thiệp 3 tháng.

4.6. Đánh giá tình trạng lâm sàng của bệnh nhân sau can thiệp. Kết quả theo dõi về lâm sàng sau điều trị ít nhất 3 tháng, so sánh với lâm sàng trước khi can thiệp, tỷ lệ khỏi hoàn toàn là $53,3 \%$, giảm nhe các triệu chứng so với trước can thiệp là $26,7 \%$, có $13,3 \%$ trường hợp lâm sàng ổn định, không thây diễn biến nặng lên, và 1 trường hợp $(6,7 \%)$ là nặng hơn so với trước can thiệp. Đánh giá các bệnh nhân theo thang điểm Rankin cải tiến, phần lớn bệnh nhân $(86,7 \%)$ sau can thiệp không gặp di chứng nào (53,3\% mRs 0, 38,5\% mRs 1$)$, chỉ có 6,7\% bệnh nhân gặp di chứng vừa (mRs 2 ) và $6,7 \%$ bệnh nhân có di chứng nặng (mRs 5).

\section{KẾT LUẬN}

Kết hợp bơm bóng chẹn bảo vệ xoang tĩnh mạch với bơm Onyx đường động mạch điêu trị RĐTMMC cho kết quả điều trị tắc đường rò cao và hạn chế các tai biến

\section{TÀI LIỆ THAM KHẢO}

1. Cognard, $\mathbf{C}_{\text {., }}$ et al.. Cerebral dural arteriovenous fistulas: clinical and angiographic correlation with a revised classification of venous drainage. Radiology. 1995; 194(3): 671-680.

2. Cognard, C., et al.. Endovascular therapy and long-term results for intracranial dural arteriovenous fistulae. In: Connors JJ, Woiak JC. editors. Interventional Neuroradioloav: Strateqies and Practical Techniaues. ed 1. Philadelphia: W.B. Saunders Co.. 1999; 198-214.

3. Alturki, A. Y., Enriquez-Marulanda, A., Schmalz, P., et al.. Transarterial Onyx Embolization of Bilateral Transverse-Sigmoid Dural Arteriovenous Malformation with Transvenous Balloon Assist-Initial U.S. Experience with Copernic RC Venous Remodeling Balloon. World Neurosurgery. 2018; 109: 398-402.

4. Lu, D., Chen, L., Kang, X.. The application of Copernic RC balloon in endovascular treatment for complex intracranial dural arteriovenous fistula of the transverse-siamoid sinus. World Neurosuraerv. 2019

5. Guo, F., Zhana, Y., Liana, S., et al.. The Procedure-Related Complications of Transarterial Onvx Embolization of Dural Arteriovenous Fistula Usina Transvenous Balloon Protection. World Neurosurgery. 2018; 116: e203-e210.

6. Vollherbst, D. F., Ulfert, C., Neuberger, U., et al.Endovascular Treatment of Dural Arteriovenous Fistulas Using Transarterial Liquid Embolization in Combination with Transvenous Balloon-Assisted Protection of the Venous Sinus. American Journal of Neuroradiology. 2018; 39(7): 1296-1302

\title{
KẾT QUẢ CHỨC NĂNG SAU CẮT ĐOẠN XƯƠNG MANG BƯớU VÀ GHÉP CHỎM XƯƠNG MÁC TỰ THÂN KHÔNG Có CUỐNG MẠCH MÁU KÈM TÁI TẠO DÂY CHẰNG QUAY TRỤ DƯớI TRONG ĐIỀU TRI BƯỚU ĐẠI BÀO ĐẦU DƯỚI XƯO'NG QUAY
}

\author{
Nguyễn Văn Hiến*, Lê Chí Dũng*, Diệp Thế Hòa*, \\ Đoàn Long Vân*, Lê Văn Thọ*
}

\section{TÓM TẮT}

Mục tiêu: Đánh giá kết qữa chức năng và các biến chứng trong và sau khi phẫu thuật điều trị bướu đại bào đâu dưới xương quay (BĐ̈BĐDXQ). Đối tượng và phương pháp nghiên cứu: nghiên cứu

*Bênh viên Chấn Thương Chinhh hình, Tp.HCM

Chịu trách nhiệm chính: Nguyễn Văn Hiến

Email: bshienctch@yahoo.com.vn

Ngày nhận bài: 7.01.2021

Ngày phản biện khoa học: 5.3.2021

Ngày duyệt bài: 15.3.2021 can thiệp không nhóm chứng với cõ̃ mẫu 50 bệnh nhân ( $\geq 18$ tuổi) bị BĐBĐDXQ được phấu thuật cắt đoạn xương mang bướu, ghép chỏm xương mác tự thân không có cuống mạch, kèm tái tạo dây chằng khớp quay trụ dưới (DCKQTD) bằng gấn cơ gan tay dài tại Khoa Bệnh học Cơ Xương khớp, BV Chấn Thương Chỉnh hình TpHCM tự 1/2010-6/2020. Kết quả: Thời gian theo dõi sau phẫu thuật là $51,9 \pm 27,9$ tháng. Kết quả đo tầm độ khớp có trung bình gập là $25,9^{0}$, duỗi là $49,7^{\circ}$, nghiểng quay $12,8^{\circ}$, nghiêng trụ $29,7^{\circ}$ sấp $52,3^{\circ}$, ngửa $68,4^{\circ}$. Sức cầm nắm của tay bị bướu so với tay lành cùng bên có tỉ lệ trung bình là $70 \%$, so với tay cùng bên không bệnh là 69,9\%. Sau 
phẫu thuật các bệnh nhân đều có chức năng chi tốt và rất tốt chiếm tỉ lệ lần lượt là $82 \%$ và $16 \%$. Tất cả bệnh nhân đều lành xương ghép với thời gian trung bình là 7,2 tháng và $100 \%$ đều không mất vững khớp gối ngoài, khớp quay cổ tay và khớp quay trụ dưới. Tuy nhiên, có $14 \%$ sau phẫu thuật có biến chứng gãy xương và $6 \%$ thoái hóa khớp độ 3 . Kết luận: bệnh nhân sau điều trị BĐBĐDXQ có kêt quả về chức nẳng tốt. Tuy nhiên, có một số trường hỡp có biến chứng gãy xương và thoái hóa khớp sau phẫu thuật.

Tư khóa: Bướu đại bào, đâuu dưới xương quay, chức năng

\section{SUMMARY}

FUNCTIONAL OUTCOME AFTER TREATMENT GIANT CELL TUMORS OF THE DISTAL RADIUS BY EN BLOC RESECTION AND RECONSTRUCTION BY NONVASCULARISED PROXIMAL FIBULAR AUTOGRAFT WITH DISTAL RADIOULNAR LIGAMENT RECONSTRUCTION

Objectives: Evaluating results of functional and complications during and after treatment giant cell tumors of the distal radius. Methods: We conducted a non-control intervention study, selected all 50 patients, aged 18 years and older with giant cell tumors of the distal radius treated by en bloc resection and reconstruction by non-vascularised proximal fibular autograft with distal radioulnar ligament reconstruction at Faculty of Musculoskeletal Pathology, Ho Chi Minh City Hospital of Trauma and Orthopedics from January 2010 - June 2020. Results: Mean follow-up time was $51.9 \pm 27.9$ months. In wrist, average range of motion achieved at last followup was $25.9^{\circ}$ of palmar flexion, $49.7^{0}$ of dorsiflexion, $12.8^{\circ}$ of tilt rotation, $29.7^{0}$ of tilt cylinder, $52.3^{0}$ of pronation turning, $68.4^{0}$ of supination. The holding power of the humped hand compared to the healthy hand had an average rate of $70 \%$, compared with the hand with the same side without disease was $69.9 \%$. All patients healed bone graft with an average time of 7.2 months and $100 \%$ of patients did not lose the joint of the lateral knee, the radio carpal and distal radioulnar joint. However, $14 \%$ of postoperative patients have complications with fracture and $6 \%$ have degenerative joint complications with degree 3 . Conclusion: After treatment, patients giant cell tumors of the distal radius have good functional results. However, there are a number of cases with complications of fracture and degeneration after surgery.

Key words: Gaint cell tumor of bone, distal radius

\section{I. ĐẶT VẤN ĐỀ}

Bướu đại bào xương (BĐBX) là loại bướu hay gặp, chiếm khoảng $14,1 \%$ các bướu xương nguyên phát và đứng hàng thứ 3 sau sarcôm tạo xương và bướu sụn xương. BĐBX là bướu lành, nhưng hay xâm lấn tại chổ và được xếp vào nhóm giáp biên ác[1]. Hiện nay, điều trị BĐBĐDXQ, vẫn còn là một thách thức vì yêu câu cân phải lấy hết bướu nhưng vẫn giữ tối đa chức năng chi. Trong khi bướu thường phát hiện trễ, mô mềm xung quanh ít, gân đâu dưới xương trụ, các xương cổ tay và các cấu trúc thân kinh, mạch máu, gân và bướu hay phá vỡ vỏ xương ra bên ngoài.

Do nạo bướu kèm ghép xương có tỉ lệ tái phát cao từ 25\% - 80\%[8]. Vì vậy, cân phải mở rông bờ nao bằng máy mài cao tốc kết hợp với các phương pháp điêu tri hỗ trợ nhưng sẽ có nhiêu biến chứng. Do đó, trong điêu trị BĐBĐDXQ, chủ yếu là cắt đoạn xương mang bướu và tái tạo khuyết hổng xương. Kết quả chức năng, phụ thuộc vào từng phương pháp tái tạo khuyết hổng xương. Cho đến nay, phương pháp ghép chỏm xương mác tự thân không có cuống mach được sử dụng rông rải. Tuy nhiên, kêt quả chức năng cổ tay chưa thật tốt, do chưa phục hồi tối đa các cấu trúc giải phẫu ở cổ tay sau cắt đoạn xương mang bướu.

Tai Việt Nam, đã có một số công trình nghiên cứu về BĐBX, nhưng chỉ có công trình của Đoàn Long Vân và cộng sự báo cáo về kết quả điều trị BĐBĐDXQ, trong đó, kết quả chức năng cổ tay của nhóm cắt rộng bướu và ghép xương là rất hạn chế [2].

Cổ tay người có chức năng làm các động tác tinh vi phức tạp, trong đó, sấp ngửa cổ tay thông qua sấp ngửa cẳng tay, là quan trọng trong hâu hết các hoạt động hàng ngày. Mất xoay cẳng tay được bù trừ bởi sự xoay trong và ngoài của cánh tay và khuỷu, nhưng điều này sẽ dấn đến nguy cơ cao về thoái hóa chóp xoay. Cẳng tay bi giới hạn sấp ngửa là một trở ngại thực sự, hâu hết là do mất vững khớp quay trụ dưới nghiêm trọng. DCKQTD là thành phân giữ vững chính của khớp quay trụ dưới.

Nghiên cứu này được thực hiện nhằm cung cấp thêm các thông tin về kết quả chức năng chi sau điêu trị BĐBĐDXQ, bằng phương pháp ghép chỏm xương mác tự thân không có cuống mạch, kèm tái tạo DCQTD bằng gân cơ gan tay dài.

Muc tiêu: Đánh giá kết quả về chức năng chi và các biến chứng trong, sau điêu trị $\mathrm{B} Đ B Đ D X Q$, bằng phương pháp ghép chỏm xương mác tư thân không có cuống mạch, kèm tái tạo DCQTD bằng gân cơ gan tay dài tại Khoa Bệnh học Cơ xương khớp, bệnh viện Chấn Thương chỉnh hình Tp.HCM.

\section{II. ĐỐI TƯỢNG VÀ PHƯƠNG PHÁP NGHIÊN CỨU}

Nghiên cứu can thiệp không nhóm chứng, thực hiện trên 50 bệnh nhân BĐBĐDXQ ( $\geq 18$ tuổi) tại Khoa Bệnh học Cơ Xương Khớp, BV Chấn thương Chỉnh hình Tp.HCM trong thời gian 
từ 01/2010- 6/2020, bằng phương pháp phẫu thuật cắt đoạn xương mang bướu kèm ghép xương mác tự thân không có cuống mạch và tái tạo DCKQTD bằng gân cơ gan tay dài theo lối vào giữa trước cổ tay.

Đánh giá chức năng chi: độ $X$ quang theo Campanacci, đo tầm độ khớp bằng thước đo góc, đo sức cầm nắm bàn tay bằng thước Jama, chức năng chi được đánh giá theo bảng đánh giá chức năng chi của Hội Bảo Tồn Chi Quốc Tế và Hội Bướu Cơ Xương Khớp, độ vững của khớp gối ngoài được đánh giá bằng dùng nghiệm pháp vẹo trong khi gối gấp 30 độ và xương chày ở tư thế trung tính, sự mất vững chia làm 3 độ. Đánh giá liên xương ghép trên $X$ quang dựa theo Hsu gồm bờ xương bên ngoài phải liên tục giữa xương chủ và xương ghép, đường cắt xương mờ hoặc rất hiếm thấy[6]. Thoái hóa khớp được đánh giá theo độ 0- không thoái hóa khớp, độ 1hẹp nhe khe khớp, độ 2- hẹp khe khớp nhiều, độ 3-không thấy khe khớp, chồi xương và bọc xương dưới sụn.

Thu thập, nhập liệu và phân tích số liệu:

Thu thập: từ hồ sơ bệnh án và khám trực tiếp bệnh nhân. Nhập liệu bằng Excel 2010 và phân tích bằng phần mềm Stata 13.0.

Vấn đề y đức: Nghiên cứu đã đước thông qua hội đồng y đức của Đại học Y Dược Tp.HCM theo quyết định số 449/HĐĐĐ-ĐHYD.

\section{KẾT QUẢ NGHIÊN CứU}

\section{Đăc điểm của mẫu nghiên cứu}

Bảng 1: Đặc điểm của mấu nghiên cứu $(n=50)$

\begin{tabular}{|c|c|c|}
\hline Các đặc điểm & $\begin{array}{c}\text { Tân số } \\
\text { (n) }\end{array}$ & $\begin{array}{l}\text { Tỉ lế } \\
(\%)\end{array}$ \\
\hline Tuối (TB \pm ĐLC, NN-LN) & $33,4 \pm 8$ & \\
\hline \multicolumn{3}{|l|}{ Giới tính } \\
\hline Nữ & 21 & 42,0 \\
\hline Nam & 29 & 58,0 \\
\hline $\begin{array}{c}\text { Kích thước bướu (cm) (TB } \\
\pm Đ L C, N N-L N)\end{array}$ & \multicolumn{2}{|c|}{$\begin{array}{c}4,1 \pm 1,5(2,7- \\
10,5)\end{array}$} \\
\hline \multicolumn{3}{|c|}{ Gãy xương bệnh lý } \\
\hline Có & 2 & 4,0 \\
\hline Không & 48 & 96,0 \\
\hline \multicolumn{3}{|l|}{ Độ X quang } \\
\hline Độ 1-2 & 0 & 0 \\
\hline Độ 3 & 50 & 100,0 \\
\hline \multicolumn{3}{|c|}{ Tái phát trước phâu thuâtt } \\
\hline Có & 2 & 4,0 \\
\hline Không & 48 & 96,0 \\
\hline \multicolumn{3}{|c|}{ Tay thuận bị bướu } \\
\hline Có & 24 & 48,0 \\
\hline Không & 26 & 52,0 \\
\hline
\end{tabular}

\begin{tabular}{|c|c|c|}
\hline $\begin{array}{l}\text { Thời gian theo dõi sau } \\
\text { phâuu thuâât (tháng) } \\
\text { (TB } \pm \oplus L C, N N-L N)\end{array}$ & \multicolumn{2}{|c|}{$\begin{array}{c}51,9 \pm 27,9 \\
(6-121)\end{array}$} \\
\hline $\begin{array}{c}\text { Chiêuu dài đoạn xương } \\
\text { ghép (cm) } \\
(T B \pm \oplus L C, N N-L N)\end{array}$ & \multicolumn{2}{|c|}{$\begin{array}{l}6,4 \pm 1,2 \\
(4,8-11,2)\end{array}$} \\
\hline $\begin{array}{l}\text { Vị trí lấy xương ghép } \\
\text { Lây xương mác cùng bên với } \\
\text { bên bị bướu }\end{array}$ & 50 & 100,0 \\
\hline
\end{tabular}

Đối tượng nghiên cứu có tuối trung bình là $33,4 \pm 8,7$, nam $58 \%$. Kích thước trung bình của bướu là $33,4 \pm 8,7 \mathrm{~cm}$. Tỉ lệ gãy xương bệnh lý là $4 \%$, tất cả bệnh nhân đều có $X$ quang độ 3 . Tî lệ tái phát trước phẫu thuật là $2 \%$, có $48 \%$ bị bướu ở tay thuận. Trung bình chiều dài đoạn xương ghép là $6,4 \pm 1,2 \mathrm{~cm}$, và toàn bộ đều có vị trí lây xương ghép là xương mác cùng bên với bên bi bướu.

Kểt quả về chức năng

Bảng 2: Kêt quả về chức năng $(n=50)$

\begin{tabular}{|c|c|c|}
\hline \multirow{2}{*}{\multicolumn{3}{|c|}{ Tầm độ khớp $(n=49)$}} \\
\hline & & \\
\hline Gập & $25,9 \pm 16,1$ & $5-$ \\
\hline Duối & $49,7 \pm 21,2$ & $5-$ \\
\hline Nghiêng quay & $12,8 \pm 3,0$ & $10-$ \\
\hline Nghiêng trụ & $29,7 \pm 10,4$ & $0-$ \\
\hline Sấp & $52,3 \pm 18,3$ & $15-8$ \\
\hline Ngửa & $68,4 \pm 21,0$ & $0-9$ \\
\hline
\end{tabular}

Sức câm nắm $(\mathbf{n}=49)$

\begin{tabular}{|c|c|c|}
\hline $\begin{array}{l}\text { Sức cầm nắm của tay bị } \\
\text { bướu (kgf) }\end{array}$ & $15,4 \pm 7,2$ & $6-28$ \\
\hline $\begin{array}{l}\text { Sức câm nắm tay bị bướu } \\
\text { so với tay lành }\end{array}$ & $70,0 \pm 15,3$ & $\begin{array}{r}44,4 \\
100\end{array}$ \\
\hline $\begin{array}{l}\text { Sức cầm nắm ta } \\
\text { o với tay cùng } \\
\text { bênh }\end{array}$ & $69,9 \pm 15,8$ & \\
\hline
\end{tabular}

\begin{tabular}{ll|l} 
so với tay cùng bên không & $69,9 \pm 15,8$ & 46,4 \\
97,2
\end{tabular}

\begin{tabular}{|c|c|c|}
\hline \multicolumn{3}{|c|}{ Chức năng chi } \\
\hline Điếm trung bình & $26,2 \pm 3,7$ & $6-29$ \\
\hline Rất tốt (đạt 90 - 100\%) & 41 & 82,0 \\
\hline Tốt (đạt 70 - 90\%) & 8 & 16,0 \\
\hline $\begin{array}{c}\text { Trung bình } \\
\text { (đạt } 50-<70 \%)\end{array}$ & 0 & 0 \\
\hline Xấu (đạt < 50\%) & 1 & 2,0 \\
\hline $\begin{array}{l}\text { Lành xương ghép } \\
\text { Thới gian lành xương ghép } \\
\text { (tháng) }\end{array}$ & $\begin{array}{c}50 \\
7,2 \pm 1,2\end{array}$ & $\begin{array}{c}100 \\
6-10\end{array}$ \\
\hline \multicolumn{3}{|c|}{ Độ vững của khớp gối ngoài } \\
\hline Không mất vững & 50 & 100,0 \\
\hline Mất vững & 0 & 0,0 \\
\hline \multicolumn{3}{|c|}{$\begin{array}{l}\text { Độ vững của khớp quay cố tay và khớp } \\
\text { quay trụ dưới }\end{array}$} \\
\hline Không mất vững & 50 & 100,0 \\
\hline Mất vững & 0 & 0,0 \\
\hline
\end{tabular}

(1 trường hợp tái phát sau điều trị được phẫu 
thuât đoan chi do đó không ghi nhận về tầm độ khớp và sức cầm nắm)

Kết quả đo tầm độ khớp có trung bình gập là $25,9^{\circ}$, duỗi là $49,7^{0}$, nghiêng quay $12,8^{\circ}$, nghiêng trụ $29,7^{0}$ sấp $52,3^{\circ}$, ngửa $68,4^{\circ}$. Sức cầm nắm trung bình của tay bị bướu là 15,4kgf. Sức cầm nắm của tay bị bướu so với tay lành có tỉ lệ trung bình là $70 \%$, so với tay cùng bên không bệnh là $69,9 \%$. Đánh giá về chức năng chi cho thấy hầu hết sau phẫu thuật các bệnh nhân đều có chức năng chi tốt và rất tốt chiếm tỉ lệ lần lượt là $82 \%$ và $16 \%$. Trung bình thời gian lành xương ghép của bênh nhân là 7,2 tháng. Tất cả các bênh nhân đều không mất vững khớp gối ngoài, khớp quay cổ tay và khớp quay trụ dưới.

Các biến chứng trong và sau phẫu thuât

Bảng 3: Các biến chứng trong và sau phẫu thuật $(n=50)$

\begin{tabular}{|c|c|c|}
\hline Biến chứng & $\begin{array}{l}\text { Tân } \\
\text { số (n) }\end{array}$ & $\begin{array}{l}\text { Tỉ lệ } \\
(\%)\end{array}$ \\
\hline \multicolumn{3}{|c|}{ Biến chứng trong lúc phâu thuật } \\
\hline $\begin{array}{l}\text { Tốn thương mạch máu, thần } \\
\text { kinh vầ gân }\end{array}$ & 0 & 0 \\
\hline \multicolumn{3}{|c|}{ Biến chứng sau phâu thuật } \\
\hline $\begin{array}{l}\text { Nhiêm trùng/Không lành } \\
\text { xương/Trật khớp quay cổ tay }\end{array}$ & 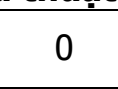 & 0 \\
\hline Gãy xương ghép & 7 & 14,0 \\
\hline Thoái hóa khớp & & \\
\hline Độ 0 & 12 & 24,0 \\
\hline Độ 1 & 25 & 50,0 \\
\hline Độ 2 & 10 & 20,0 \\
\hline Độ 3 & 3 & 6,0 \\
\hline $\begin{array}{c}\text { Thời gian bị gãy xương } \\
\text { ghép (tháng) } \\
T B \pm D L C, N N-L N\end{array}$ & \multicolumn{2}{|c|}{$\begin{array}{l}17,0 \pm 6,6 \\
(9-14)\end{array}$} \\
\hline
\end{tabular}

Nghiên cứu chưa ghi nhận trường hợp có biến chứng trong lúc phẫu thuật. Tuy nhiên, có $14 \%$ bệnh nhân sau phẫu thuật có biến chứng bị gãy xương và $6 \%$ có biến chứng thoái hóa khớp độ 3.

\section{BÀN LUÂN}

4.1 Các đặc điểm của mẫu nghiên cứu. BĐB xương thường xảy ra ở xương người trưởng thành từ 30-40 tuổi. Nghiên cứu của chúng tôi cho thấy tuổi trung bình của bệnh nhân là 33,4 $\pm 8,7$ tuổi. Thời gian theo dõi trung bình sau phẫu thuật của chúng tôi là $51,9 \pm 27,9$ tháng. Thời gian này gần bằng với nghiên cứu của Chadha và cộng sự (2010) 56 tháng[3], nhưng thấp hơn của Chung và cộng sự (2012) với 6,26 năm[4]. Ngoài ra, nghiên cứu chúng tôi cho thây nam chiếm $58 \%$. Trung bình kích thước bướu là $33,4 \pm 8,7 \mathrm{~cm}$, có $4 \%$ bị gãy xương bệnh lý trước phẫu thuật, $2 \%$ bị tái phát trước phẫu thuật, $48 \%$ bị bướu ở tay thuận và tất cả bệnh nhân đều có $X$ quang ở độ 3.

4.2 Vị trí lấy xương ghép, tạo hình khớp. Hâuu hết các tác giả đều thích lấy xương mác đối bên vì có thể thực hiện đồng thời với cắt bướu và giải phẫu gần giống đâu dưới xương quay. Theo nghiên cứu của Chung (2012) cho thấy vững khớp không phụ thuộc vào chọn lựa bên lấy xương mác, mà tùy thuộc vào sở thích của phẫu thuật viên[4]. Trong nghiên cứu này, chúng tôi lấy xương mác cùng bên vì có thể lấy cùng 1 lúc với cắt bướu và tổn thương ở cùng 1 bên nên bệnh nhân dễ tập vật lý trị liệu.

Đối với các bướu ở giai đoạn 2, hàng xương đầu ở cổ tay được giữ nên có thể tạo hình khớp hoặc hàn khớp 1 phần. Do còn khớp giữa cổ tay nên 1 số hoạt động cổ tay vẫn còn. Tuy nhiên, vùng tiếp xúc giửa xương mác - thuyền- nguyệt có giới han nên khó hàn khớp và cần cố định lâu dài để liền xương [4]. Trong nghiên cứu của chúng tôi, tất cả bướu đều ở giai đoạn 3 nhưng chúng tôi đều giữ được hàng xương đầu ở cổ tay, cho phép tạo hình khớp sau ghép chỏm xương mác và đoạn xương ghép trung bình $6,4 \mathrm{~cm}$ do đó chúng tôi ghép chỏm xương mác không có cuống mạch.

\subsection{Kết quả về chức năng}

Tâm độ khớp. Có nhiều phương pháp tái tạo khuyết hỗng xương sau cắt đoạn xương quay mang bướu mỗi phương pháp có đều có ưu điểm, tuy nhiên cũng có những nhược điểm như ghép xương quay đồng loại có thể không lành xương, gãy xương ghép, thoái hóa khớp. Chuyển xương trụ có cuống mạch có bất lợi là đường kính phần xa cẳng tay bị hẹp tạo hình ảnh đồng hồ cát gây ảnh hưởng thẩm mỹ. Ghép xương mào chậu thì chiều dài mảnh ghép bị giới hạn. Thay khớp nhân taoo có thể gây nhiễm khuẩn và lỏng dụng cụ. Ghép chỏm xương mác có cuống mạch vẫn còn nhiều bàn cãi về lựa chọn mạch máu lây kèm chỏm mác.

Theo Vander Griend cho rằng lợi ích của ghép xương mác có cuống mạch ít quan trọng đối với đầu dưới xương quay, do đoạn xương ghép tương đối ngắn, khả năng bao phủ ít nhất phần cửa mảnh ghép với cơ duỗi ngón cái và cơ duỗi cố tay trụ và sử dụng nẹp cố đinh vững chắc giúp bảo vệ mãnh ghép tránh gãy mệt, trong khi chờ đợi mảnh ghép tái tạo mach máu và tái tạo mẫu[8]. Nghiên cứu của chúng tôi chọn ghép chỏm xương mác không có cuống mạch.

Để đat được độ vững của khớp cổ tay sau ghép chỏm xương mác nhiều tác giả đề nghị 
khâu hoặc tái tạo ít nhất 1 dây chằng. Tuy nhiên, nghiên cứu của Chung có khâu dây chằng bên mác với dây chằng bên quay nhưng cũng có $5 / 12$ trường hợp bị mất vững khớp cổ tay[4]. Chúng tôi chưa ghi nhận các nghiên cứu tái tạo dây chằng quay trụ dưới sau ghép chỏm xương mác trong điều trị bướu đại bào đầu dưới xương quay.

Cổ tay người có chức năng làm các động tác tinh vi phức tạp, trong đó sấp ngửa cổ tay thông qua sấp ngửa cẳng tay, là quan trọng trong hầu hết các hoạt động hàng ngày. Cẳng tay bị giới hạn sấp ngửa hầu hết là do mất vững khớp quay trụ dưới. DCQTD là thành phần giữ vững chính của khớp quay trụ dưới. Trong nghiên cứu này chúng tôi thực hiện tái tạo DCKQTD bằng gân cơ tay dài.

Theo nghiên cứu của Palmer và cộng sự thì tầm vận động chức năng của cổ tay người bình thường là gập $5^{\circ}$, duỗi $30^{\circ}$, nghiêng quay $10^{\circ}$, nghiêng trụ $15^{0}$. Hầu hết các hoạt động hàng ngày nằm trong biên độ này[7]. Kết quả đo tầm độ khớp của chúng tôi cho thấy trung bình gập là $25,9^{\circ}$, duối là $49,7^{0}$, nghiêng quay $12,8^{\circ}$, nghiêng trụ $29,7^{0}$ sấp $52,3^{\circ}$, ngửa $68,4^{\circ}$. Như vậy cho thấy các biên độ vận động của bệnh nhân sau điều trị đã trở lại gần như bình thường. Riêng vận động gập còn bị giới hạn, điều này là do bao khớp chầy mác trên phía trước dày hơn nên khi ghép xương mác cùng bên thì phía trước xương mác sẽ trở thành phía sau khi ghép vào xương quay và khi khâu dây chằng bao khớp "mác cổ tay" chỉ có thể khâu được mặt lưng nên gây hạn chế gập.

Sức câm nắm. Kết quả của chúng tôi cho thây sức cầm nắm của tay bị bướu có trung bình là 15,4 kgf, tỉ lệ sức cầm nắm của tay bị bướu so với tay lành trung bình là $70,0 \%$. Kết quả này khả quan hơn so với nghiên cứu của Chadha và cộng sự với tỉ lệ sức cấm nắm của tay bị bướu so với tay lành chỉ đạt 29,5\%[3], Chung và công sự $(57,25 \%)[4]$, điêu này là do chúng tôi tái tạo DCKQTD nên làm tăng độ vững của khớp quay trụ dưới và khớp quay cổ tay nên làm tăng sức cầm nắm. Do sức cầm nắm ở tay không thuận giảm $10 \%$ so với tay thuận, nên chúng tôi ghi nhận thêm tî lệ sức cầm nắm so với tay cùng bên không bệnh là 69,9\%.

Chức năng chi. Kết quả đánh giá cho thấy điểm trung bình chức năng chi sau điêu trị là 26,2 điểm, tương ứng với $82 \%$ có chức năng chi tốt và $16 \%$ rất tốt. Chỉ có 1 bệnh nhân (2\%) bị tái phát xâm lấn ra sát da nên phải đoạn chi. Tương đồng với nghiên cứu của Chung và cộng sự với điểm chức năng trung bình là 26,4 điểm[4].
Độ vững ổn của khớp gối ngoài: Cắt chỏm xương mác cùng với dây chằng bám vào nó có thể gây ra bất thường về dáng và mất vững khớp gối. Draganich và cộng sự báo cáo sự tăng dịch chuyển phía trước và trước sau của gổi khi gấp, xoay vẹo ngoài -vẹo trong ở $20^{\circ}$ gấp và vài bất thường khi di chuyển. Draganich đề nghị rằng các rối loạn này có thể hạn chế tối đa bằng cách đính lại đúng cách dây chằng bên ngoài và gân nhị đầu đùi ở vị trí mới [5]. Trong nghiên cứu này chúng tôi có thực hiện đính lại nơi bám dây chằng bên ngoài và gân nhị đầu vào xương chày do đó kết quả cho thấy $100 \%$ bệnh nhân của sau điều trị đều không mất vững.

Các biến chứng. Kết quả chúng tôi chưa ghi nhân trường hợp nào có biến chứng trong lúc phẫu thuật. Tuy nhiên, sau phẫu thuật có $7 / 50$ trường hợp bị gãy xương ghép (với thời gian gãy xương trung bình là $17,0 \pm 6,6$ tháng). Trong đó, 3 trường hợp gãy xương ở tay thuận bị bướu, vị trí gãy 7 trường hợp này đều ở dưới nẹp (do không được phần nẹp nâng đỡ nên dễ bị gãy). Trong đó có 1 trường hợp được xử trí bằng phẫu thuật cắt ngắn xương trụ, ghép xương mào chậu và kết hợp xương, 5 trường hợp được ghép xương mào chậu và kết hợp xương, 01 trường hợp từ chối điều trị. Thoái hóa ở khớp quay cổ tay độ 3 được ghi nhận trên 3 bệnh nhân. Trong nghiên cứu của chúng tôi không có trường hợp nào bị biến chứng nhiễm trùng hay không lành xương và trât khớp quay cổ tay. Các biến chứng sau phẫu thuật của chúng tôi ít hơn so với Chadha và cộng sự với gãy xương ghép sau phẫu thuật 12 và 15 tháng là $2 / 9$ trường hợp $(22,2 \%)$, nhiếm trùng $(1 / 9)$ $11,1 \%$, liệt dây thần kinh do garo (1/9) $11,1 \%$, thoái hóa khớp (1/9) 11,1\% [3].

\section{KẾT LUÂ̂N}

Kết quá điều trị $B Đ B \boxminus D X Q$ bằng phương pháp cắt rộng bướu, ghép chỏm xương mác tự thân không có cuống mạch, kèm tái tạo DCQTD bằng gân cơ gan tay dài cho kết quả về chức năng tốt. Tuy nhiên có $14 \%$ bệnh nhân có biến chứng gãy xương và $6 \%$ bị thoái hóa khớp độ 3.

\section{TÀI LIÊU THAM KHẢO}

1. Lê Chí Dũng (2003) Bướu xương: Lâm sàngHình ảnh $Y$ học- Giải phẩu bệnh và Điều trị,, Nhà xuất bản Y học- chi nhánh Tp.HCM, tr. 1-392.

2. Đoà̀n Long Vân, Lê Chí Dũng, Nguyễn Văn Thẳng (1998) "Điều trị bướu đại bào xương đầu dưới xương quay bằng phẫu thuật". Đề tài nghiên cứu khoa học câp cơ sở, TT.CTCH Sở Y tế TP.HCM, tr.1-9.

3. Chadha M, Arora SS, et al (2010) "Autogenous non-vascularized Wbula for treatment of giant cell 
tumor of distal end radius". Arch Orthop Trauma Surg, 130, 1467-1473.

4. Chung DW, Han CS, Lee JH, Lee SG (2012) "Outcomes of wrist arthroplasty using a fre vascularized fibular head graft for enneking stage ii giant cell tumors of the distal radius". Microsurgery, doi 10.1002/micr, pp.1-7.

5. Draganich LF, Nicholas RW, Shusther JK, Sathy MR, Chang AF, Simon MA (1991) "The effects of resection of the proximal part of the fibula on stability of the knee and on gait". J Bone Joint Surg Am, 73A(4), 575-83.
6. Hsu RWW, Wood MB, Sim FH, Chao EYS (1997) "Free vascularised fibular grafting for reconstruction after tumour resection". The Journal of Bone and Joint Surgery, vol. 79-b, no. 1

7. Palmer AK, Dobyns JH, Linscheid RL, Elsevier (1978) "Management of post-traumatic instability of the wrist secondary to ligament rupture". The Journal of hand surgery, Volume 3, Issue 6, Pages 507-532.

8. Vander Griend RA, Funerburk CH (1993) "The treatment of giant cell tumors of the distal part of the radius". JBJS, $75 \mathrm{~A}(6)$, 899- 908.

\section{KẾT QUẢ ĐIỀU TRI BẢO TỒN GÃY XƯƠNG TRÂ̂T KHỚP Có ĐẮP THUỐC NAM TẠI KHOA KHÁM XƯƠ'NG VÀ ĐIỀU TRI NGOẠI TRÚ, BỆNH VIỆN HN VIỆT ĐỨC}

\section{TÓM TẮT}

Nghiên cứu được tiến hành trên 57 bệnh nhân gãy xương, trật khớp, chấn thương phần mềm, được điêu trị bảo tồn tồn tại khoa Khám xương và điêuu trị ngoại trú bệnh viện Việt Đức, trước đó bệnh nhân được điều trị ban đầu bằng đắp thuốc nam (bó lá). Mục tiêu: mô tả một số đặc điểm lâm sàng của gãy xương trật khớp có đắp thuốc nam và kết quả điều trị. Pháp nghiên cứu: Mô tả các đặc điểm lâm sàng 57 bệnh nhân gãy xương, trật khớp, chấn thương phần mềm được điều tri ban đầu bằng đắp thuốc nam, ghi nhân kết quả sau điều trị. Kết quả: Có 23/31 trường hợp gãy xương, sau bó bột ổ gãy xương vẫn còn nguyển di lệch; 3/11 trường hợp trật khớp, bán trật khớp, nắn chưa về giải phẫu; 35/57 trường hợp có viêm da tiếp xúc, $9 / 57$ trường hợp nhiễm trùng phần mềm liên quan bó lá. Đa phân người bệnh đến bó lá tại các cơ cở y tế tự phát, đông y gia truyền. Có 38/57 bệnh nhân đạt kết quả trung bình và kém sau điêuu trị. Kết luận: Xương gãy không được nắn chỉnh về giải phẫu, khồng được bất động tốt, kèm theo đó là viêm da tiếp xúc, nhiếm trùng phân mềm liên quan đến đắp lá là những yếu tố chính ảnh hưởng đến kết quả điều trị.

Tư khoá: nhiếm trùng phần mềm, gãy xương, trật khớp, thuốc nam, bó lá

\section{SUMMARY}

RESULTS OF CONSERVATIONAL TREATMENT FOR PATIENTS WITH BONE
FRACTURE AND JOINT DISLOCATION,
TREATED BY SOUTH MEDICINE AT THE

\author{
${ }^{1}$ Bệnh viện Việt Đức \\ 2Đại họ Y Hà Nội \\ Chịu trách nhiệm chính: Dương Đình Toàn \\ Email: toanduongdinh@gmail.com \\ Ngày nhận bài: 6.01.2021 \\ Ngày phản biện khoa học: 8.3.2021 \\ Ngày duyệt bài: 16.3.2021
}

Dương Đình Toàn ${ }^{1,2}$

\section{OUTPATIENT CLINIC, VIET DUC HOSPITAL}

The study was conducted on 57 patients with bone fractures, joint dislocations, softtissue injuries, conserved and treated at the outpatient clinic of Viet Duc Hospital, before that the patients were initially treated with south medicine (leaf bundles). Objectives: describe some clinical signs of dislocated fractures and joint dislocations, softtissue injuries with south medicine application and the results of treatment. Methodology: Describe the clinical features of 57 patients with bone fractures, dislocations, and software injuries that were initially treated with traditional medicine (south medicine), recording post-treatment results. Results: There were 23 out of 31 cases of fractures. 3/11 cases of dislocated joints have not yet been corrected anatomically; 35/57 cases have dermatitis, 9/57 cases of softtissue infections related to leaf bundles. 38/57 patients achieved average and poor results after treatment. Conclusion: Fractured bone is not corrected anatomically, is not inactive well, dermatitis, softtisue infections related to leaf bundles are the main factors affecting treatment results.

Keywords: softtisue infections, dermatitis, leaf bundles, south medicine

\section{I. ĐẶT VẤN ĐỀ}

Thuốc nam từ lâu được xem là môt loai dược liệu, được người dân sử dụng trong điều trị mộ số bệnh thồng thường, mang lại hiệu quả nhất định. Trong gãy xương trật khớp, thuốc nam có vai trò giảm sưng tiêu viêm, tăng cường tuần hoàn tại chỗ, có thể thúc đẩy quá trình chống viêm, liền xướng [1]. Với vai trò như trên, thuốc nam sẽ phát huy được tác dụng nếu xương gãy hay khớp trât đã được nắn về vị trí giải phẩu và được bất động tốt. Tuy nhiên hiện nay phong trào chữa bệnh bằng thuốc nam tự phát đang ngày càng nở rộ, khó kiểm soát về chất lượng thuốc cũng như 